\title{
Greenhouse and field assessment of different organic compounds against guava-parasitic Meloidogyne enterolobii
}

\author{
Alexandre Macedo Almeida; Ricardo Moreira Souza (*); Vicente Martins Gomes; Guilherme Bessa \\ Miranda
}

Universidade Estadual do Norte Fluminense Darcy Ribeiro, Laboratório de Entomologia e Fitopatologia, Av. Alberto Lamego, 2000, 28013-620 Campos dos Goytacazes (RJ), Brasil.

(*) Corresponding author: ricmsouza@censanet.com.br

Received: June 29, 2011; Accepted: Dec.16, 2011

\begin{abstract}
Guava decline is a complex disease involving Meloidogyne enterolobii and Fusarium solani and it has caused major direct losses to Brazilian growers. Although several strategies have been sought to control the nematode, the use of organic soil amendments is currently the best approach to manage this disease. To assess the best amount of meat and bone meal (MBM) to be incorporated into the soil, guava seedlings inoculated with $M$. enterolobii were treated with $1-5 \% \mathrm{v} / \mathrm{v}$ of the MBM. Ninety days later variables related to nematode reproduction and plant development were evaluated, which indicated a potential nematicidal effect of the MBM at 3\%. Another experiment assessed nematode- and plant-related variables 90 days after treatment of the seedlings with MBM, chitosan, shrimp shell or neem cake at 3\%, $0.05 \%, 2 \%$ and $0.1 \% \mathrm{v} / \mathrm{v}$, respectively. The MBM ranked first, reducing nematode reproduction. This MBM rate was converted to $25 \mathrm{~kg} / \mathrm{tree}$ and assessed in three application regimes (monthly, bimonthly or trimonthly), for six months, in an orchard affected by guava decline. The variables assessed were soil density of colony forming units (CFU) of bacteria and fungus, and soil and/or root density of M. enterolobii, Helicotylenchus sp., and of different nematode trophic groups. In all three application regimes the MBM reduced all plantparasitic nematodes in the soil and the fungus CFUs. It also promoted an increase in bacterial CFU and bacterivorous nematodes.
\end{abstract}

Key words: Psidium guajava, Fusarium solani, neem cake, chitosan, shrimp shell, cultural control, guava decline, meat and bone meal.

\section{Avaliação em casa de vegetação e em campo de diferentes compostos orgânicos contra Meloidogyne enterolobii}

\section{Resumo}

O declínio da goiabeira, uma doença complexa envolvendo Meloidogyne enterolobii e Fusarium solani, tem causado grandes prejuízos diretos para os produtores brasileiros. Apesar de várias estratégias terem sido discutidas para o controle do nematoide, a utilização de matéria orgânica adicionada ao solo é atualmente a melhor abordagem para conviver com essa doença. Para avaliar a dose adequada de farinha de carne e ossos (FCO) a ser incorporada ao solo, mudas de goiabeira inoculadas com M. enterolobii foram tratadas com 1-5\% v/v da FCO. Noventa dias após foram avaliadas variáveis relacionadas à reprodução do nematoide e ao desenvolvimento das plantas, indicando um possível efeito nematicida da FCO a 3\%. Outro experimento avaliou variáveis relacionadas ao nematoide e à planta 90 dias após o tratamento das mudas com FCO, quitosana, casca de camarão e torta de nem a 3\%, 0,05\%, 2\% e 0,1\% v/v, respectivamente. A FCO reduziu a reprodução do nematoide, destacando-se em relação aos demais tratamentos. Esta dosagem de FCO foi convertida para $25 \mathrm{~kg}$ planta-1 $\mathrm{e}$ avaliada em três regimes de aplicação (mensal, bimestral ou trimestral), por seis meses, em pomar de goiaba acometido pelo declínio. As variáveis avaliadas foram densidade no solo de unidades formadoras de colônia (UFC) de bactérias e fungos, e a densidade no solo e/ou raiz de M. enterolobii, Helicotylenchus sp., e de diferentes grupos tróficos de nematoides. Em todos os três regimes de aplicação a FCO reduziu todos os nematoides parasitas de plantas no solo e o número de UFC de fungos, e promoveu aumento no número de UFC de bactérias e nematoides bacteriofagos.

Palavras-chave: Psidium guajava, Fusarium solani, torta de nim, quitosana, casca de camarão, controle cultural, declínio da goiabeira, farinha de carne e ossos. 


\section{INTRODUCTION}

The guava (Psidium guajava L.) (Myrtaceae) is a robust fruit-bearing tree that originated in the American tropics; its current distribution covers all the tropical and subtropical regions of the world (Gonzaga Neto and Soares, 1994). In Brazil, guava cultivation is typically practiced by smallholders, with annual turnover of about US\$ 38 million, involving many agro-industries and productive chains for machinery and pesticides (IвGE, 2009).

Guava decline is a complex disease caused by the synergistic association between Meloidogyne enterolobii Yang and Eisenback, 1983 and Fusarium solani (Mart.) Sacc. (Gomes et al., 2011). In this disease, F. solani-immune guava trees become susceptible to extensive necrosis of the root system caused by this fungus upon parasitism by $M$. enterolobii. Assays conducted with F. solani isolates from different Brazilian regions confirmed that guava decline is responsible for exterminating about 5000 hectares of orchards throughout Brazil, with direct losses estimated to stand at more than US\$ 70 million (Pereira et al., 2009).

As an agent that predisposes the plant to guava decline, $M$. enterolobii has been the target of various control strategies, as yet without success. These include biological control with fungi, bacteria and entomopathogenic nematodes, leaving fallow and using nematicides (CASASSA et al., 1996; Gueye et al., 1997; Duponnois et al., 1998; Moreira et al., 2001; Brito et al., 2004; Rocha et al., 2004; Souza et al., 2006; Carneiro et al., 2007; Charchar et al., 2007; Lopes et al., 2009; Ока, 2010; Almeida et al., 2011). Burla et al. (2010) and Miranda (2012), among others, have identified genotypes or accessions of Psidium spp. that are resistant to M. enterolobii. Nonetheless, guava producers are unlikely to have commercially available resistant cultivars or rootstocks for some years to come.

Gomes et al. (2010) managed a commercial guava plantation affected by guava decline using applications of organic soil amendments, obtaining major yield gains in comparison to untreated plants. The use of cow manure and poultry compost provided better results than sugarcane filter cake; this agrees with previous reports on other plant-parasitic nematodes, which indicate that the nature of the organic matter determines its nematicidal efficiency, along with biota and chemical properties of the soil (Akhtar and Alam, 1993; Akhtar and Malik, 2000; Ferraz et al., 2010). Several organic soil amendments have been used with success to manage plant-parasitic nematodes, such as neem (Azadirachta indica A. Juss) cake (Silva and Pereira, 2008), chitin-rich products (Galper et al., 1990), meat and bone meal (MBM) and several kinds of waste products (Aкhtar and Alam, 1993). However, the recommendation for use of any of these amendments depends on the pathosystem: whether it is an annual or perennial crop, the nematode genus and/or species involved, and whether the nematode is associated (or not) with another soil pathogen. The availability of the organic matter source, its cost for purchase and application at the recommended dosage and crop profitability are also aspects that need consideration.

Hence, the present study reports efforts to assess in greenhouse the effect of neem cake, shrimp shell, chitosan and MBM applied as soil amendment on $M$. enterolobii and on the vegetative development of guava seedlings. Since there are no reports on the amount of ammonium released through microbial degradation of the particular MBM used in this study, nor its effect on $M$. enterolobii, a preliminary dose-response assessment was conducted for this product. Promising results were obtained in greenhouse for MBM (see results), so this product was further tested in a commercial guava plantation affected by guava decline to assess its effect on root and/or soil density of bacterivore, mycophagus, predatory and plant-parasitic nematodes (including the abundant Helicotylenchus sp. and $M$. enterolobii), and on the soil density of colony forming units (CFUs) of bacteria and fungi. The influence of MBM on soil chemistry and plant nutrition was also investigated.

\section{MATERIAL AND METHODS}

\section{Greenhouse assessment of different organic soil amendments}

\section{Seedling production and inoculation with M. enterolobii}

Guava seedlings of cultivar Paluma were produced from true seeds in plastic bags filled with Plantmax ${ }^{\circledR}$ substrate for plant growth. At the stage of four leaves, they were transplanted to $2 \mathrm{~L}$ plastic pots filled with washed riverbed sand homogenized with 2000 eggs and secondstage juveniles $\left(\mathrm{J}_{2}\right)$ of $M$. enterolobii. The seedlings were maintained in greenhouse with mean high and mean low temperatures of $36.6^{\circ} \mathrm{C}$ and $21^{\circ} \mathrm{C}$, respectively, and they were watered and fertilized as necessary.

The nematode inoculum used was obtained from guava roots that were washed in tap water and put in $3 \mathrm{~L}$ glass vials containing $1.5 \mathrm{~L}$ of an aqueous solution at $6 \%$ of $\mathrm{QBoa}^{\circledR}$ commercial bleach (sodium hypochlorite concentration at $2.5 \%$ ). The vials were shaken for 4 minutes at 130 cycles per minute using the TE-240 $\mathrm{Tecnal}^{\circledR}$ shaker. The suspension was poured through layered sieves with 60 and 500 mesh, and the nematode concentration was obtained counting on a Peters` slide in three aliquots of $1 \mathrm{~mL} /$ plant.

\section{Assessment of dosage for MBM use}

Thirty days after nematode inoculation, the MBM (produced by Respa Ltda, Campos dos Goytacazes, Brazil), was incorporated at $0-3 \mathrm{~cm}$ depth in the sand, at 1,2 , 
3,4 or $5 \% \mathrm{v} / \mathrm{v}$ relative to the volume of $2 \mathrm{~L}$ of sand. Plants inoculated with the nematode that received no MBM served as control. These treatments were arranged in an entirely randomized pattern, with six replicates (one plant/pot) per treatment. The average composition of the MBM is dry matter $(94 \%)$, crude protein (42\%), crude fat $(12 \%)$, mineral content $(38 \%)$, calcium $(14 \%)$, phosphorus $(6 \%)$, chlorine $(0.5 \%)$ and sodium $(0.7 \%)$.

Ninety days after MBM application plant height was measured, and the root systems were individually washed in tap water. The root system volume $\left(\mathrm{cm}^{3}\right)$ was measured through water displacement in a laboratory graduated cylinder. The plant shoot and roots were fresh weighed. For nematode extraction and counting, the roots were processed as described before. The following nematode variables were assessed: final nematode population $(\mathrm{Fp})=\left(\right.$ number of eggs $\left.+\mathrm{J}_{2}\right) /$ root system, $\mathrm{Fp} / \mathrm{g}$ of root, and reproduction factor $(\mathrm{RF})=\mathrm{Fp} / 2000$. All data were submitted to ANOVA and to regression analysis through SAEG $^{\circledR}$ software (RIBEIRo JúNIOR, 2001).

\section{Assessment of different organic soil amendments}

Guava 'Paluma' seedlings were produced and inoculated as described before. Thirty days after nematode inoculation the following amendments were incorporated at $0-3 \mathrm{~cm}$ depth in the sand: chitosan at $0.05 \% \mathrm{v} / \mathrm{v}$, or shrimp shell at $2 \% \mathrm{v} / \mathrm{v}$, or neem cake at $0.1 \% \mathrm{v} / \mathrm{v}$, or MBM at $3 \% \mathrm{v} / \mathrm{v}$ (as recommended by the first experiment - see results). Inoculated, untreated plants served as control. The five treatments were arranged in an entirely randomized pattern, with six replicates (one plant/pot) per treatment. Ninety days after amendment application the same variables described before were analyzed by ANOVA and compared through Tukey's test at $5 \%$ of probability.

\section{Effect of MBM on soil bacteria, fungi, and nematofauna in a commercial orchard}

The guava 'Paluma' orchard was five years old, planted with $7 \times 7$ meter spacing, and located in the municipality of São João da Barra (lat. 2141'22”S; long. 41'3'20”W). The orchard was irrigated by sprinklers as needed, and the management of pests and diseases [mainly psilids (Triozoida sp.) and rust (caused by Puccinia psiddi Winter)] was carried out with pesticides at the recommended rates. Organic fertilization was conducted with $60 \mathrm{~kg}$ of mature bovine manure per tree twice a year, and chemical fertilization with $300 \mathrm{~g}$ per tree of 20-5-20 formulation every three weeks in the period between plant trimming and the beginning of harvest. The orchard was infested by M. enterolobii (mean density at $60 \mathrm{~J}_{2} 100 \mathrm{~cm}^{-3}$ of soil) and some trees showed the typical symptoms of guava decline: chlorosis, scorching of edges, leaf wilt and fall, abundant root galling and root rot. As regards plant-parasitic nematodes, the orchard soil harbored also Criconema sp., Mesocriconema sp., Pratylenchus sp., Hemicycliophora sp., and abundant Helicotylenchus sp..

In greenhouse, the best nematode control was obtained with $\mathrm{MBM}$ at $3 \% \mathrm{v} / \mathrm{v}$. For the field assessment, this rate was converted to $1.2 \mathrm{~kg}$ of MBM per square meter under the tree canopy (equivalent in this orchard to $25 \mathrm{~kg}$ per tree). For application, plant debris was removed from soil surface and the MBM was evenly spread by hand under the canopy. The product was superficially incorporated with a rake and the plant debris was returned under the canopy. Through-irrigation was then applied.

The dosage of $25 \mathrm{~kg}$ of MBM per tree was assessed in three application regimes: monthly, bimonthly and trimonthly. For the monthly treatment, the MBM was applied in July/2009 through January/2010. For the bimonthly treatment, the applications were done in July, September and November/2009, and January/2010. For the trimonthly treatment, the applications were in July and October/2009, and January/2010. Untreated plants served as control. These four treatments were arranged in randomized blocks, with six replicates (trees) per treatment. One planting line was kept as a buffer between blocks, and within planting lines two buffer trees were kept between the trees assigned for data collection.

Soil and/or root nematode density was assessed in July, August and October/2009, and January/2010 for all treatments, just prior to MBM applications. Soil and root samples were collected under the trees' canopy, at 0-15 cm depth, with a $15 \mathrm{~cm}$ high, $7 \mathrm{~cm}$ diameter auger $\left(-500 \mathrm{~cm}^{3}\right)$. Two subsamples were collected on opposite sides of each of the 24 experimental trees, and taken to the laboratory. For each composite sample, the roots were separated and weighed, and the root mass was expressed as g per sampling. The composite samples were individually homogenized and an aliquot of $100 \mathrm{~cm}^{3}$ of soil was processed for nematode extraction according to JENKINS (1964). The nematode density was calculated from three counts of $1 \mathrm{~mL}$ aliquots of the nematode suspension obtained. The densities evaluated per $100 \mathrm{~cm}^{3}$ of soil were $\mathrm{J}_{2}$ of M. enterolobii, specimens of Helicotylenchus sp., and total specimens of the following trophic groups: plant-parasitic, mycophagus, bacterivorous and predatory. In the roots, the variables evaluated were $M$. enterolobii-induced root galls per $\mathrm{g}$ of roots and per sampling. The data were submitted to ANOVA and the treatments were compared through Tukey's test at 5\% confidence.

Soil density of CFUs of bacteria and fungi were assessed in October/2009 for all treatments. Soil samples were collected as described before, from which aliquots of $10 \mathrm{~g}$ were suspended in $100 \mathrm{~mL}$ of sterile $0.85 \%$ saline solution. Before sedimentation of the soil particles, an aliquot of $1 \mathrm{~mL}$ was pipetted out of the suspension and serially diluted to $10^{-4}$ through $10^{-6}$ for fungus isolation, and to $10^{-5}$ through $10^{-7}$ for bacterial isolation. For isolation of 
Fusarium sp., the diluted suspensions were incubated in Petri dishes with the Fusarium sp.-selective medium proposed by MARTIN (1950), supplemented with $60 \mathrm{mg} \mathrm{mL}^{-1}$ of streptomycin sulphate and $70 \mathrm{mg} \mathrm{mL}^{-1}$ of stain Rose Bengal. For bacteria isolation, the nutrient agar medium was supplemented with $10 \mu \mathrm{g} \mathrm{mL} \mathrm{m}^{-1}$ of cyclohexamide.
The Petri dishes were turned upside down for incubation at $28{ }^{\circ} \mathrm{C}$ in a $12 / 12$ photoperiod, during 3-7 days. The resulting CFUs were counted under magnifying lens.

In July, November and December/2009 foliar and soil samples were collected for assessment of plant nutrition (macro- and micronutrients) and soil chemistry $(\mathrm{pH}$,
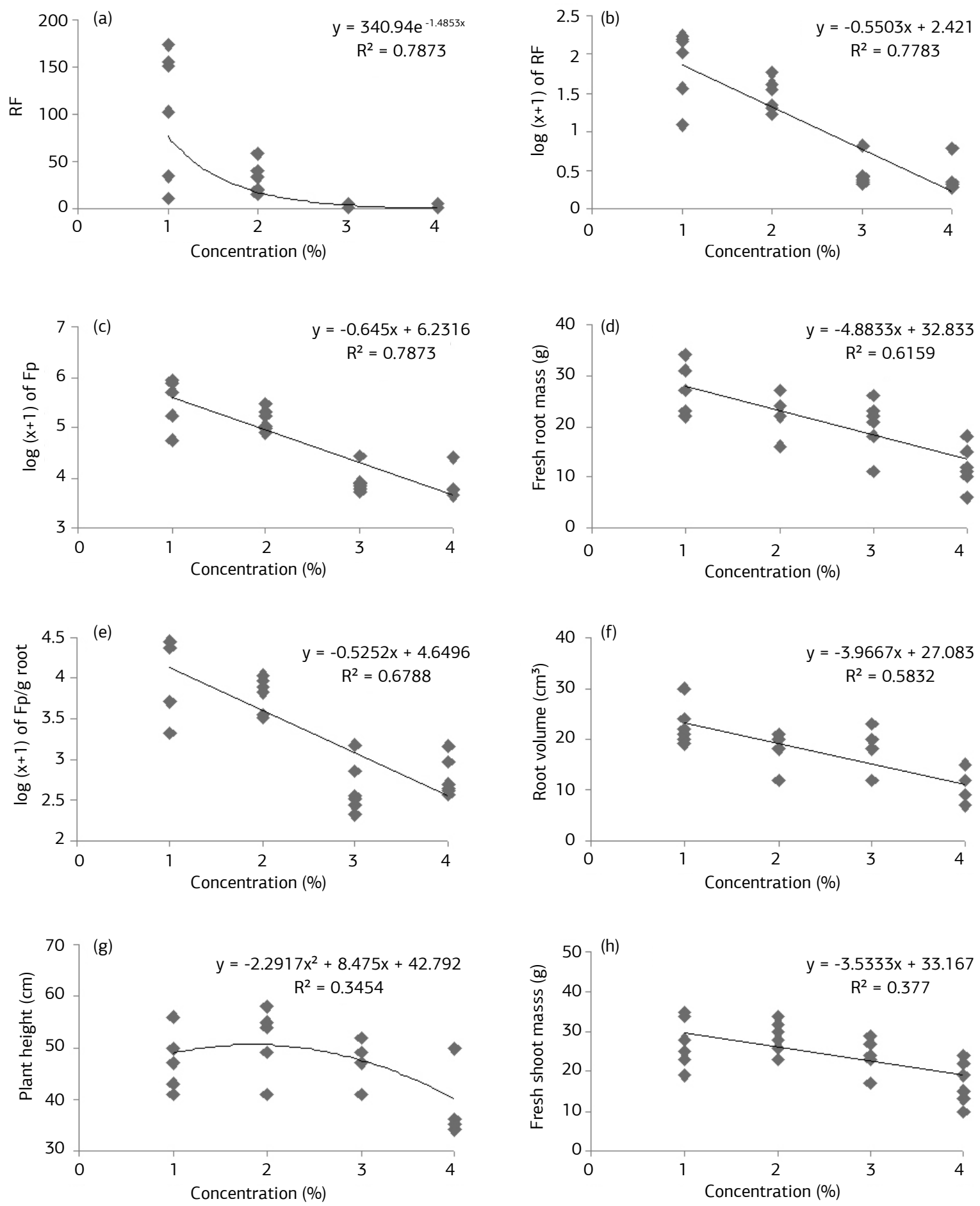

Figure 1. Regression analysis of variables related to Meloidogyne enterolobii and growth of guava plants inoculated with 2000 eggs and second-stage juveniles of the nematode in greenhouse and 30 days later treated with different rates $(\% \mathrm{v} / \mathrm{v}$, relative to volume of the substrate soil) of meat and bone meal (MBM). The MBM was incorporated superficially into the soil, and the evaluations occurred 90 days later. $\mathrm{Fp}=$ final nematode population; Reproduction factor $(\mathrm{RF})=\mathrm{Fp} / 2000$. 
organic matter content, macro- and micronutrients). The results were compared to recommendations for guava cultivation (SALVADOR et al., 2000).

\section{RESULTS AND DISCUSSION}

In greenhouse, the variables related to $M$. enterolobii and plant development decreased $(\mathrm{p}<0.05)$ with the increase of concentration of MBM (1-4\% v/v) (Figure 1). A phytotoxic effect may have occurred at $4 \%$, since most plants presented the least root (Figure 2) and shoot development, and all plants at 5\% died two weeks after MBM application. Therefore, this experiment suggested a potential benefit of MBM at $3 \% \mathrm{v} / \mathrm{v}$, although it did not clearly demonstrate a nematicidal effect of this product, since the decrease in nematode-related variables may have been secondary to lesser plant development or to toxicity.

Upon comparison with other soil amendments in a second greenhouse experiment, MBM at $3 \% \mathrm{v} / \mathrm{v}$ was better in reducing $(\mathrm{p}<0.05)$ all variables related to nematode reproduction (Table 1), and it promoted

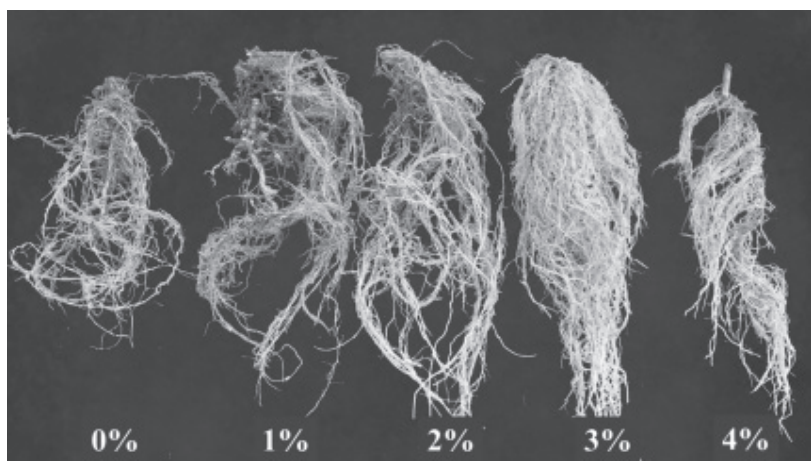

Figure 2. Root system of guava plants inoculated with 2000 eggs and second-stage juveniles of Meloidogyne enterolobii in greenhouse and 30 days later treated with different rates (\% v/v, relative to volume of the substrate soil) of meat and bone meal (MBM). The MBM was incorporated superficially into the soil, and the evaluations occurred 90 days later. From left to right: untreated control, 1, 2, 3, and 4\%. gains $(\mathrm{p}<0.05)$ in plant development, particularly for the roots (Figure 3). This nematicidal effect could be related to release of nitrogen-rich compounds in the soil, such as urea and ammonium nitrate, following the microbial degradation of the MBM (RodRIGUEZKabana, 1986). According to Eno et al. (1955), ammonium nitrate causes nematode cell plasmolysis when at a concentration above $300 \mathrm{mg} \mathrm{kg}^{-1}$ of soil. Neem cake was as good at promoting plant development, but it presented no nematicidal effect, since Fp and RF actually increased in comparison with the control check. Therefore, although the neem cake was used at the dosage recommended by the manufacturer, the results do not line up with several reports on its nematicidal effect (Ferraz et al., 2010). Despite reports on the nematicidal properties of chitosan and shrimp shell, in this experiment they faired the worst in reducing nematode reproduction.

Guavadeclinecan beseen as a complex diseaseinvolving two pathogens with distinct interactions with plant root. As a biotrophic, obligatory parasite, $M$. enterolobii is favored by an abundant root system, while the invasion

Table 1. Variables related to Meloidogyne enterolobii and growth of guava plants inoculated with 2000 eggs and second-stage juveniles $\left(\mathrm{J}_{2}\right)$ of the nematode, and 30 days later treated with different organic soil amendments, at different rates (\% v/v) relative to volume of substrate. The amendments were incorporated superficially to the soil, and the evaluations were performed 90 days later

\begin{tabular}{|c|c|c|c|c|c|c|c|}
\hline Treatments & $\mathrm{Fp}^{1} \times 1000$ & $\mathbf{R F}^{2}$ & $\begin{array}{l}\text { Fresh root } \\
\text { system mass } \\
\text { (g) }\end{array}$ & $\begin{array}{l}\text { Fp.gram } \\
\text { roots }^{-1} \\
(\times 1000)\end{array}$ & $\begin{array}{l}\text { Fresh root } \\
\text { system } \\
\text { volume }\left(\mathrm{cm}^{3}\right)\end{array}$ & $\begin{array}{l}\text { Fresh shoot } \\
\text { mass }(\mathrm{g})\end{array}$ & $\begin{array}{l}\text { Plant height } \\
\text { (cm) }\end{array}$ \\
\hline Untreated control & $63.4 \mathrm{~b}$ & $31.7 \mathrm{~b}$ & $7.1 \mathrm{c}$ & 10.20 bc & $5.3 \mathrm{~b}$ & $5.2 \mathrm{c}$ & $25.8 \mathrm{c}$ \\
\hline Chitosan (0.05\%) & $255.7 \mathrm{a}$ & $127.8 \mathrm{a}$ & $8.8 \mathrm{c}$ & $29.60 \mathrm{a}$ & $7.3 \mathrm{~b}$ & $6.7 c$ & $26.6 c$ \\
\hline Shrimp shell (2\%) & $65.6 \mathrm{~b}$ & $32.8 \mathrm{~b}$ & $18.1 \mathrm{~b}$ & $3.70 \mathrm{~cd}$ & $17.5 \mathrm{a}$ & $14.6 \mathrm{~b}$ & $39.5 b$ \\
\hline Neem cake $(0.1 \%)$ & $305.4 \mathrm{a}$ & $152.7 \mathrm{a}$ & $27.1 \mathrm{a}$ & $11.80 \mathrm{~b}$ & $20.6 \mathrm{a}$ & $24.0 \mathrm{a}$ & $43.6 \mathrm{ab}$ \\
\hline Meat and bone meal (3\%) & $10.3 c$ & $5.1 \mathrm{c}$ & $20.1 \mathrm{~b}$ & $0.65 d$ & $17.5 \mathrm{a}$ & $24.0 \mathrm{a}$ & $47.1 \mathrm{a}$ \\
\hline CV (\%) & 2.8 & 7.7 & 22.3 & 38.7 & 25.1 & 20.4 & 9.5 \\
\hline
\end{tabular}

(') Fp (final nematode population) $=$ eggs $+\mathrm{J}_{2} \cdot$ root system ${ }^{-1} \cdot\left({ }^{2}\right) \mathrm{RF}$ (reproduction factor) $=\mathrm{Fp} \cdot 2000^{-1}$

Values are average of six replicates (one plant/pot) per treatment.

Values followed by different letters in the column are different according to Tukey's test at $\mathrm{p}<0.05$. 
of $F$ solani results in root rot, plant and yield decline. Different variables related to nematode reproduction, abundance of roots, root rot and productivity have been assessed for this disease (BurLa et al., 2010; Gomes et al., 2010; 2011; Miranda et al., 2011). In this work, as previously observed by BurLa et al. (2010), the variable $\mathrm{Fp} / \mathrm{g}$ of root was less informative than Fp and RF.

In the six-month field experiment, MBM promoted a reduction $(\mathrm{p}<0.05)$ in the soil density of $M$. enterolobii $\mathrm{J}_{2}$ in all three regime applications tested (Table 2). This reduction resulted in no decrease in root galling density, possibly because a substantial $\mathrm{J}_{2}$ population remained in the soil to infect the guava roots. Also, a reduction $(\mathrm{p}<0.05)$ occurred in the density of plantparasitic nematodes, and of Helicotylenchus sp. in particular (Table 3). In addition to releasing urea and ammonium nitrate, the degradation of MBM could also increase the soil biota antagonistic to plant-parasitic nematodes. Indeed, MBM promoted an increase in the soil density of bacteria and bacterivorous nematodes, a phenomenon often associated with biological control of soil-dwelling plant-parasitic nematodes through amendment with organic matter (MCSORLEY and Frederick, 1999; OKA, 2010).
An aspect that prompted an on-going investigation was the reduction $(p<0.05)$ in the soil density of fungi in all application regimes of MBM. Although this quantification was performed using Fusarium-selective medium, other fungi grew in the Petri dishes. It is conceivable that this product may have an antagonistic effect on $F$ solani, a property that could offer a reduction in the severity of guava decline.

In addition to its potential role in controlling $M$. enterolobii, the use of MBM could have additional benefits for the chemistry and structure of the soil, and plant fertilization (Malavolta et al., 2000). In this field experiment, the three analyses conducted on soil chemistry and plant nutrition revealed values (data not shown) that were within the ranges recommended for guava cultivation.

Unfortunately, the effect of the MBM on productivity could not be assessed because the orchard 's last pruning was not uniform across the experimental plot, which would invariably affect the treatment's productivity. A two-year long experiment has been set up in three different commercial orchards to further evaluate the effect of different rates and regime applications of the MBM on the soil density of $M$. enterolobii and $F$ solani, the incidence and severity of guava decline, and productivity.

Table 2. Variables related to Meloidogyne enterolobii in a commercial guava orchard affected by guava decline and treated for six months with $25 \mathrm{~kg} \mathrm{tree}^{-1}$ of meat and bone meal as a soil amendment under different application regimes, in São João da Barra, Brazil

\begin{tabular}{|c|c|c|c|c|}
\hline Treatments & $\begin{array}{l}\text { Density of } J_{2} \text { per } \\
100 \mathrm{~cm}^{3} \text { of soil }\end{array}$ & $\begin{array}{l}\text { Density of root galls } \\
\text { per sampling core } \text { corl }^{(1)}\end{array}$ & $\begin{array}{l}\text { Fresh root mass per } \\
\text { sampling core }\end{array}$ & $\begin{array}{c}\text { Density of root galls per } \\
\text { g of root }\end{array}$ \\
\hline Untreated control & $81.94 \mathrm{a}$ & $204.5^{\text {ns }}$ & $111.76^{\mathrm{ns}}$ & $11.45^{\text {ns }}$ \\
\hline Monthly applications & $35.83 b$ & 133.2 & 98.93 & 13.05 \\
\hline Bimonthly applications & $36.44 \mathrm{~b}$ & 172.4 & 108.79 & 13.32 \\
\hline Trimonthly applications & $30.94 b$ & 232.1 & 104.60 & 15.89 \\
\hline CV (\%) & 63.45 & 24.26 & 34.66 & 139.9 \\
\hline
\end{tabular}

(') Sampling performed with an auger of about $500 \mathrm{~cm}^{3}$ capacity.

Values are average of six trees per treatment in four evaluations (July, August, October/2009, and January/2010) for each treatment.

In the columns, "ns" indicates that values are not different according to Tukey's test $(\mathrm{p}<0.05)$. Values followed by different letters in the column are different according to Tukey's test at $\mathrm{p}<0.05$.

Table 3. Soil density of different groups of nematodes $\left(\right.$ per $\left.100 \mathrm{~cm}^{3}\right)$ and of bacteria and fungi $\left(\right.$ per $\left.\mathrm{cm}^{3}\right)$ in a commercial guava orchard affected by guava decline and treated for six months with $25 \mathrm{~kg}$ tree ${ }^{-1}$ of meat and bone meal as a soil amendment under different application regimes, in São João da Barra, Brazil

\begin{tabular}{|c|c|c|c|c|c|c|c|}
\hline Treatments & $\begin{array}{c}\text { Fauna of } \\
\text { plant-parasitic } \\
\text { nematodes }\end{array}$ & Helicotylenchus sp. & $\begin{array}{c}\text { Bacterivorous } \\
\text { nematodes }\end{array}$ & $\begin{array}{c}\text { CFU of } \\
\text { bacteria }\end{array}$ & $\begin{array}{l}\text { Mycophagous } \\
\text { nematodes }\end{array}$ & $\begin{array}{l}\text { CFU of } \\
\text { fungus }\end{array}$ & $\begin{array}{l}\text { Predatory } \\
\text { nematodes }\end{array}$ \\
\hline Untreated control & $483.3 \mathrm{a}$ & 206.7 a & $187.8 \mathrm{~b}$ & $1.25 \times 10^{10} \mathrm{C}$ & $38.9^{\text {ns }}$ & $2.45 \times 10^{8} \mathrm{a}$ & $11.1^{\text {ns }}$ \\
\hline $\begin{array}{l}\text { Monthly } \\
\text { applications }\end{array}$ & $44.4 \mathrm{~b}$ & $11.1 \mathrm{~b}$ & $1290.0 \mathrm{a}$ & $1.24 \times 10^{10} \mathrm{C}$ & 12.2 & $4.96 \times 10^{6} \mathrm{~b}$ & 0.0 \\
\hline $\begin{array}{l}\text { Bimonthly } \\
\text { applications }\end{array}$ & $72.2 \mathrm{~b}$ & $27.8 \mathrm{~b}$ & $1381.1 \mathrm{a}$ & $2.48 \times 10^{10} \mathrm{~b}$ & 12.3 & $7.36 \times 10^{6} \mathrm{~b}$ & 4.4 \\
\hline $\begin{array}{l}\text { Trimonthly } \\
\text { applications }\end{array}$ & $67.8 \mathrm{~b}$ & $33.3 \mathrm{~b}$ & $676.7 \mathrm{ab}$ & $3.16 \times 10^{10} \mathrm{a}$ & 20.0 & $6.11 \times 10^{6} \mathrm{~b}$ & 7.8 \\
\hline CV (\%) & 118.1 & 146.0 & 54.2 & 10.1 & 109.8 & 33.8 & 155.1 \\
\hline
\end{tabular}

(1) Fauna composed of Criconema sp., Mesocriconema sp., Pratylenchus sp., Hemicycliophora sp., Helicotylenchus sp. and Meloidogyne enterolobii.Values are average of six trees per treatment in four evaluations (July, August, October/2009, and January/2010) for each treatment.

In the columns, "ns" indicates that values are not different according to Tukey's test ( $<<0.05)$. Values followed by different letters in the column are different according to Tukey's test at $\mathrm{p}<0.05$. 
These orchards have been selected to accommodate different technological levels of guava production and different levels of severity of guava decline.

\section{CONCLUSION}

In greenhouse, the MBM at 3\% v/v showed potential as a organic soil amendment against $M$. enterolobii, ranking first among other amendments tested. In the field, MBM applied monthly, bimonthly or trimonthly at $25 \mathrm{~kg} /$ tree reduced the soil density of fungus CFUs, M. enterolobii, Helicotylenchus sp. and total plant-parasitic nematodes, while it increased bacteria CFUs and bacterivorous nematodes.

\section{REFERENCES}

AKHTAR, M.; ALAM, M.M. Utilization of waste materials in nematode control. A review. Bioresource Technology, v.45, p.1-7, 1993.

AKHATAR, M.; MALIK, A. Roles of organic soil amendments and soil organisms in the biological control of plant-parasitic nematodes: A review. Bioresource Technology, v.74, p.35-47, 2000.

ALMEIDA, A.M.; GOMES, V.M.; SOUZA, R.M. Greenhouse and field assessment of rhizobacteria to control guava decline. Bragantia, v.70, p.11-23, 2011.

BRITO, J.A.; POWERS, T.O.; MULLIN, P.G.; INSERRA, R.N.; DICKSON, D.W. Morphological and molecular characterization of Meloidogyne mayaguensis from Florida. Journal of Nematology, v.36, p.232-240, 2004.

BURLA, R.S.; SOUZA, R.M.; GOMES, V.M.; CORREAA, F.M. Comparação entre níveis de inóculo, épocas de avaliação e variáveis para seleção de Psidium spp. visando à resistência a Meloidogyne enterolobii. Nematologia Brasileira, v.34, p.82-90, 2010.

CARNEIRO, R.M.D.G.; CIROTTO, P.A.; QUINTANILHA, A.P.; SILVA, D.B.; CARNEIRO, R.G. Resistance to Meloidogyne mayaguensis in Psidium spp. accessions and their grafting compatility with $P$. guajava cv. Paluma. Fitopatologia Brasileira, v.32, p. 281-284, 2007.

CASASSA, A.M.; MATHEUS, J.M.; CROZZOH, R.; CASANOVA, A. Control químico de Meloidogyne spp. en el cultivo de guayabo (Psidium guajava L*) en el Municipio Mara del Estado Zulia, Venezuela. Revista de la Facultad de Agronomía, v.13 p.303312, 1996

CHARCHAR, J.M.; GONZAGA, V.; VIEIRA, J.V.; OLIVEIRA, V.R.; MOITA, A.W. MOITA.; ARAGĀO, F.A.S. Efeito de rotação de culturas no controle de Meloidogyne spp. Em cenoura na regiáo norte do Estado de Minas Gerais. Nematologia Brasileira v.31, p. 173-179, 2007.

DUPONNOIS, R.; BA, A.M.; MATEILLE, T. Effects of some rhizosphere bacteria for the biocontrol of nematodes of the genus
Meloidogyne with Arthrobotrys oligospora. Fundamental and Applied Nematology, v.21, p.157-163, 1998.

ENO, C.F., BLUE, W.G., GOOD, J.M., Effect of anhydrous ammonia on nematodes, fungi, bacteria and nitrification in some Florida soils. Proceedings of the Soil Science Society of America, v.19, p. 55-58, 1955.

FERRAZ, S.; FREITAS, L.G.; LOPES, E.A.; DIAS-ARIEIRA, C.R. Manejo Sustentável de Fitonematoides, Viçosa: UFV, 2010. p.71-85.

GALPER, S.; COHN, E.; SPIEGEL, Y.; CHET, I. Nematicidal effect of collagen-amended soil and the influence of protese and collagenase. Revue de Nematologie, v.13, p.67-71, 1990.

GOMES, V.M.; SOUZA, R.M.; MUSSI-DIAS, V.; SILVEIRA, S.F.; DOLINSKI, C. Guava Decline: A Complex Disease Involving Meloidogyne mayaguensis and Fusarium solani. Journal of Phytopathology, v.159, p.45-50, 2011.

GOMES, V.M.; SOUZA, R.M.; CORRÊA, F.M.; DOLINSKI, C. Management of Meloidogyne mayaguensis in commercial guava orchards with chemical fertilization and organic amendments. Nematologia Brasileira, v.34, p.23-30, 2010.

GONZAGA NETO, L.E.; SOARES, J.M. Goiaba para exportação: aspectos técnicos da produção. Brasilia: Embrapa-SPI. p.49. 1994, (Serie Publicaçôes Técnicas FRUPEX, 5)

GUEYE, M.; DUPONNOIS, R.; SAMB, P.I.; MATEILLE, T. Study on 3 strains of Arthrobotrys oligospora: biological characterization and effects on Meloidogyne mayaguensis parasitic on tomato in Senegal. Tropicultura, v.15, p.109-115, 1997.

IBGE, Produção Agrícola Municipal 2008. Lavoura Permanente. Rio de Janeiro: IBGE, 2009. Disponível na internet: http://www. ibge.gov.br. Acesso em 06/3/2010.

JENKINS, W.R. A rapid centifugal-flotation technique for separating nematodes from soil. Plant Disease Reporter, v.48, p.692, 1964.

LOPES, E.A.; S. FERRAZ, O.D.; DHINGRA, P.A.; FERREIRA, L.G.; FREITAS. Soil amendment with castor bean oilcake and jack bean seed powder to control Meloidogyne javanica on tomato roots. Nematologia Brasileira, v.33, p.106-109, 2009.

MALAVOLTA, E.; PIMENTEL, F. Adubos e adubações. 1.ed., São Paulo: Nobel. 2000.

MARTIN, J.P. Use of acid, rose bengal, and streptomycin in the plate method for estimating soil fungi. Soil Science, v.69, p.215-232, 1950.

MCSORLEY, R.; MCGOVERN, R.J. Effects of solarization and ammonium amendments on plant-parasitic nematodes. Journal of Nematology, v.32, p.537-541, Supplement. 2000.

MIRANDA, G.B.; SOUZA, R.M.; GOMES, V.M.; FERREIRA, T.F.; ALMEIDA, A.M. Avaliação de acessos de Psidium spp. quanto à resistência a Meloidogyne enterolobii. Bragantia, v. 71 p.52-58, 2012. 
MOREIRA, W.A.; BARBOSA, F.R.; MOURA, A.O. Distribuição populacional de fitonematoides em goiabeira no submedio Sao Francisco. Nematologia Brasileira, v.25, p. 125, 2001.

OKA, Y. Mechanism of nematode suppression by organic soil amendments - a review. Applied Soil Ecology, v. 44, p.101-115, 2010.

PEREIRA, F.O.M.; SOUZA, R.M.; SOUZA, P.M.; DOLINSKI, C.; SANTOS, G.K. Estimativa do Impacto Econômico e Social Direto de Meloidogyne mayaguensis na Cultura da Goiaba no Brasil. Nematologia Brasileira, v.33, p.176-181, 2009.

RIBEIRO JÚNIOR, J.I. Análises Estatísticas no SAEG. Viçosa: UFV, 2001. 301p.

ROCHA, M.R.; CARVALHO, Y.; CORRÊA, G.C.; CATTINI. G.P.; PAOLINI, G. Efeito de doses crescentes de calcário sobre a população de Heterodera glycines em soja. Pesquisa Agropecuária Tropical, v.36, p.89-94, 2006.
RODRIGUEZ-KABANA, R. Organic and inorganic nitrogen amendments to soil as nematode suppressants. Journal of Nematology, v.18, p.129-135, 1986.

SALVADOR, J.O.; MOREIRA, A.; MALAVOLTA, E.; Nutrição mineral, adubação e irrigação. In: MANICA, I.; ICUMA, I.M.; JUNQUEIRA, N.T.V. (Ed.). Goiaba: fruticultura tropical 6. Porto Alegre: Cinco Continentes, p.135-191, 2000.

SILVA, G.S.; PEREIRA, A.L. Efeito da incorporação de folhas de nim ao solo sobre o complexo Fusarium $x$ Meloidogyne em quiabeiro. Summa Phytopathologica, v.34, p.368-370, 2008.

SOUZA, R.M.; NOGUEIRA, M.S.; LIMA, I.M.; MELARATO, M.; DOLINSKI, C.M. Manejo de nematoides-das-galhas da goiabeira em Sáo João da Barra (RJ) e relato de novos hospedeiros. Nematologia Brasileira, v.30, p.165-169, 2006. 